\title{
Local Democracy without Elections: The Politics in Nepal
}

\author{
Than Bahadur Chetri
}

\begin{abstract}
The article analyzes the nature of perversion at local level in the absence of poll, controversy and conflict in local transition of Nepal at the present context. It also argues that the absence of elections at micro democratic institutions, right to vote and elect own representatives remain on paper, poor service delivery and no service delivery, the relation between the state and the citizens have further widened due to legacy of exclusionary politics. At the end, political parties are the creator of democracy; they lack a common vision to lead the society and how to live together. Federalism a new political order, is going to start; the coming days will show whether it will bring stability or instability in such society.
\end{abstract}

Keywords: Elections, federalism, participation, representatives.

\section{The Idea of Democracy}

People have wants and needs. To satisfy wants and needs, people come into contact with one another. Naturally, this gives rise to group/s. The conflict and disagreement between groups gives rise to politics. Politics requires ideas and values. Politics sets the goals and standards of political organization. Politics requires social organizations that collect interests, aggregate, and communicate them to the political and governmental institutions as well as institutions to collect proposals for the organization of society, and then represent, discuss, decide and implement them. Likewise, it requires active citizens who take part in political discussions with ideas, demands and expectations, and actively contribute to the functioning of political institutions 
(Konard Adenauer Stiftung, 2011). Thus, politics is for power and justice, it determines 'how we live together in a society' (Konard Adenauer Stiftung, 2011). Hence, 'Ideas are generated and institutions are developed' by wo/men in order to achieve peace and happiness in their lives. When institution fails to establish equality, order and justice, new institution come up, this is a common process.

Democracy is a form of government, developed against the autocratic regime. The idea of democracy, as a form of government, was developed in ancient Greeks. It was a direct democracy and in perverted from. Modern democracy is an indirect one, it is operating through the elected representative, in which citizens elect representatives to make political decisions, formulate laws and administer programs for the public good. The onward march of democracy started after the Glorious Revolution of 1688, which halted for a while during the First World War and the Second World War. Many people have lost their lives during these wars for the sake of democracy. After the war, it appeared as a popular form of government and has remained one of the most living political institutions in the world. The reason behind its popularity is that "living under democratic institutions makes people much happier than living under authoritarian institutions" (Inglehart, 2006; 1). It has the capacity to accommodate the diversity and gives priority to people's security, freedoms and human rights. Every country has been trying to achieve in their respective countries. The $19^{\text {th }}$ century is known as the 'golden age of democratic theory' and the 20 th century as the era of democratic practice. Democracy is an evolutionary process was well as dynamic, despite its popularity, it is facing numerous challenges in various parts of the world. It is not from others but from the elected representatives who are suppose to govern the nation in a democratic way. 


\section{Idea of Micro Democratic Institutions in Nepal}

Whether big or small, every country has local governments. It is an agent of social changes and a part of the national government. It works on the theme only which are related with the interest of the local community. It is not possible to govern and provide service delivery from the central level government over the local community. Modern age is an age of rapid industrialization and urbanization. The central government failed in identifying real problems and addressing all the issues of the local people. Hence, local bodies are established for the improvement of human development. On the other hand, the spread of democratic ideas, globalization and the rise of civil society have brought dissatisfactions with the central government. "Citizens often complain that governments provide services that are inadequate, inappropriate, inferior or too costly of their hard-earned tax payments" (UN, 2007; 2). Simply installation of democracy at national level is not enough to achieve democracy at local. It needs decentralization of power. Thus, the demand of decentralization of power, to make more people participate in decision making and governance became stronger. Consequently, it leads to spread of local democracy. 'No government can function without government'. 'No local government can perform effectively without decentralization'. Decentralization of power, is the indicators of measuring democracy, provide "citizen with ample opportunities for participation, civic education and training for leadership" (Thapa, 1998; 14).

The history of modern local democracy in Nepal is not so long. Historically, Nepal's local governmental institutions have enjoyed little autonomy since Prithivi Narayan Shah, successive ruler's controlled national life from Kathmandu (Key, 2013; 95). The Government Nepal Act, 1947 and the Village Panchayat Act of 1949 are the first steps in building local bodies. After 
the fall of Rana regime and the dawn of democracy, the elected government proposed an institutional arrangement for local self-government, the Royal take over in 1960, the efforts remained unimplemented. The Panchayat system created local bodies at the village, city, district and zonal levels, entrusted the role of development, programs under the active local elected representatives. It accepted the principles of decentralization and proclaimed various policies and devolved the power at the local level ranging from Thapa commissioned in 1962 to enact of the Decentralization Act in 1982 and Decentralization Rules 1984. However, it excluded the participation of 'non-panchas'; these institutions had the limited authority to formulate policy, undertake programme and levy taxes.

The local bodies are the foundation of democratic structure, in the absence of adequate practicing it in all levels, democracy cannot be institutionalized. The rival of democracy in 1990 marked a new start of the practice of local democracy through decentralization in Nepal. Realizing the importance of local governance, the article 25 (4) of the Constitution of the Kingdom of Nepal 1990, states "It the chief responsibility of the State to maintain conditions suitable to the enjoyment of the fruits of democracy through wider participation of the people in the governance of the country and by way of decentralization". To translate this principles and policies into reality, the elected government promulgated new Local Self-governance Act, 1999 and Local Governance Rules, 2000 and Financial Rules were promulgated on the basis or report prepared by the Working Committee set up under High Level Decentralization Coordination Committees, which was constituted in 1996. The LSGA Act (1999) is a comprehensive legislation that aims at promoting local democratic governance, created two tiers at local bodies. The Village Development Committee (VDCs) 
and Municipalitiy is the first tier of local bodies. Currently, they are providing frontline services at the local level. The District Development Committee (DDC), the second tier, has no territorial and jurisdiction nor serves the people directly. But, it coordinates and monitors, and works as a bridge between the central government and the village and the municipalities. The Local Self Government Act of 1999 forms the legal basis for local governance.

\section{Concepts of Local Democracy}

Democracy is a 'democratic idea', 'democratic institution', and 'democratic practice' (Dreje and Sen, 2002; 346). Democratic ideal denotes "government of the people, by the people and for the people". We can say that government comes from the people. It is exercised by the people and for the purpose of the people's own interests. But democratic institutions are the institutional arrangements, such as constitutional rights, effective courts, responsive electoral systems, functioning parliaments and assemblies, open and free media, and participatory institutions of local governance'(Dreje and Sen, 2002;346). A combination of democratic institutions and democratic practices help achieve democratic ideals. Every country in the world, except some micro states has some forms of local democracy.

Local democracy is a micro democratic institution at the local level (village, municipal, city, town, district, county, and equivalent local levels), created by the local community for the community and are responsive and accountable government to them. It is a self-government and administration closest to the people. The essential notion is that inhabitants of a given area have the right and responsibility to make decisions on those issues that affect them most directly and on which they can make decisions (IDEA, 2001;11). They are the outcomes 
of decentralization of power to larger, intermediate-level units (such as states, provinces and regions). Local democracy is an entry point of participation and representation, improve service delivery, strengthen communities, end marginalization and improve development outcomes and help build state and nation building. The local democracy may be direct or indirect, depends upon the several contexts; they are the outcomes of decentralization of power to larger, intermediate -level units (such as states, provinces and regions).

\section{Constitutional Rights and Democracy}

Modern democracy is a constitutional democracy. It provides rights to its citizens. Right to vote and the right to representation is the natural right, none can violate. The Universal Declaration of Human Rights, in Article 21, recognizes it, "everyone has the right to take part in the government of his/her country, directly or through freely chosen representatives". Every country recognizes these rights. Our constitution accepts right to vote and elect own representatives through free and fair election, a device, "for fulfilling an office or post through choices made by a designated body of people" (Heywood, 2002; 229). It is the core element of representative democracy. Constitutional rights are not enough, if they are not implemented. The election of local bodies was held in 1992, and in 1997 respectively. The tenure of the elected officials came to an end in July 2002. Since then, the local bodies are running without elected representatives. For this reason, Interim Constitution of 2007, aims to hold election to local bodies and the Article (139) the constitution states that "Election shall be held to set up local self governance bodies on the basis of principles of decentralization and devolution of power by creation a congenial atmosphere for the exercise of the people's sovereignty and they by ensuring maximum people's 
participation in the country's governance, to provide service to the people at the local level and for the institutional development of democracy".

But, the attitude of the leaders toward empowering the society remained incomplete. Instead of holding local polls, they agreed to form All Party Mechanisms (APMs), later it was dismissed in January 2012 amid charges of widespread misuse of local funds'(Asia Foundation, Nepal, 2012). The political leaders, reinstated the dissolved parliament, did not restore the dissolved local bodies. The election for the Constituent Assembly (CA) were held twice, (once in 2008 and the other in 2013), which is rarely held in the world whereas the sovereign people still deprived of the right to vote and elect own representatives at the local level. This is a glaring example of 'denial and negation of the democratic rights of the citizens'.

Democracy is for the youths. A vast majority of youths have grown up without seeing election at local level in their life. The participation of youths in politics is essential in making national politics more competitive achieving good governance and democracy. The youths played an important role in establishing democracy, in 1990 and 2006, but they deprived of the right to participation in the local elections and solicit youth's views in the field of policy making, development and in governance. Democratization involves betterment of life in comparison to autocratic regime, but there has been no improvement on the part of political rights. The high expectation of the Nepalis that emerged after the end of autocratic regime has turned into dissatisfaction. 


\section{Local Democracy without Elections}

Election, which constitutes one of the most important pillars of democracy, is used to choose representatives at various levels of governance in political democracy. Local bodies are, also known as local governments, functioning without elected since 2002. It has been remained only on papers. In the absence of democratic leadership at the local units, various forms of perversion are practicing. The following section deals with these issues under sub-heading.

\section{Political Parties and Political Socialization}

Democracy is built by human beings, what we call political party is, a group of people organized on the basis of political ideology, who come together to contest elections and hold power in the government. The political parties agree on some proposed policies and programs, with a view to promoting the collective good or furthering their supporters' interests'. They are organized at the local, state, and national levels and their role can't be denied at any level of government. The main purpose of the party is to join people, establish links between society and government, organize groups in society and involve them in debates on social issues to translate the wishes they register in society into a political program and rally support for these issues in election campaigns. The party's views and ideas implemented in policies. They pursue representation in government. Hence, a political party performs three functions: organizational function, the programmatic function, and the nomination function (Webb, 2002, cited in Boogers \& Voerman, 2010). Alexis Tocqueville, who wrote a major book about democracy, considered local government as the mainstay of local democracy. He also saw local democracy as a school of political education and a safety valve of democracy for the entire nation (De Tocqueville, \{1835- 
1840 \}, 2000 cited from Allif, 2013). They act as local political parties pursuing representation in the local council.

What kind of political parties we have in the transition to democracy is important while explaining democratic transition. It is the party organization and governance that determines the behavior political party as well as the party youth wings are functioning. Leader is to lead the society and establish a just society, but in Nepal it means to become political elite. Due to erosion in political ideology, that teaches how to establish justice and build a harmonious society, in all parties, they look like an informal club group/s, like that the shape of ginger. Due to existence of 'one's own leader and other leader'(lack 'common leader'), it is difficult to distinguish who is leading the party. Such group/s has adverse impact sisters' organization. Local politicians, the wealthiest people, bureaucrats, privileged people, district party committee members, the security persons, teachers and some health workers as well as the businessmen and the contractors are the main actors of local level. An influential leader or MP keeps the whole district under its control, by distributing government resources. The benefit goes to his/her supporters only. The party constitution, which derives from the constitution, is just to see only on paper, not to practice them honestly.

Almost all the political parties have the local party wings and committees at various levels. Elections are held for party sister organization, the interests and whims of the central leader determine the election of these organization. Party sister organizations are running without accountability, transparency in the absence of timely convention and elections, which is against the principle of constitution. As mother, as daughter, they also practise exclusionary politics. During the Panchayat 
system, the bureaucrats, MPs and the teachers were the thulo manchhe, at now it is the 'middlemen'. Like the senior leaders, the local leaders re-energized family, friend, and our man and area politics. The entry of persons with wrong background in the name of party affiliation, politics has become a profession, who are often protected by the central leaders, getting rich overnight and grabbing more and more, like bees suck honey in hive. Such malpractice has been creating inequality and the opponent does not hesitate to finish the partner too. Infighting is common in all sister organizations, parties lack capacity to govern and regulate their own organization as well as the society. Due to partial and incomplete political socialization, equality, common good, accountability towards society, consensus over common development goals are the local values of Nepalese society. All these values pushed down the hill. They are creating in new political culture, which is contributing more prone to political instability and more disruption.

\section{Poor Service Delivery and No Service Delivery System}

Public administration exists for public. Service delivery is the 'core function of local government'. Local bodies are the friends of community, people pay different kinds of tax to Local governments. They provide numerous services delivery, social security and other beneficiaries to the people through its different agencies. Effective service delivery is an effective tool of state and nation building that creates a harmonious society especially in post conflict societies. Effective polices and program of the government depends upon the bureaucrats. At local level, people face numerous problems among them are of either 'poor service delivery, or no service delivery'. Key inscribes, "Nepal's local institutions have failed to meet pressing human needs just as they had failed to do so under the old system" (Key, 2013; 107). 
The local government lacks "its ability to carry out many duties it is assigned under the Local Self Governance Act, 1999" (Key, 2013; 100). In remote areas the VDC secretaries perform their daily duty at headquarter of the district, carrying their entire materials in their bags and stay in the hotels, instead of their respective office. Thus, no one is accountable and responsible towards providing effective service delivery to the sovereign people. The security persons and the bureaucrats are the strong persons at local level. Getting effective service delivery and other government resources depends upon personal contact with them rather than its formal rule. Inequality in service delivery and corruption has been adding social disorder in Nepal. Public administration is not able to become as friendly to all especially the marginalized and other socio-economic backward people, due to huge gap between people's expectation and the delivery of public services. People's trust in the institution has been losing.

\section{Personalized and Centralized Planning}

The needs of the local people are renovation of schools, electricity lines, and construction of bridge, water tank, and irrigational canals, better health posts and road. The government has established VDCs and DDC, These bodies are responsible for construction of local schools, health centers and roads and to serve people without discrimination to poorest and marginalized people. Due to existence of traditional norms and values, the DDC members and the influential persons of VDCs always divert the plans and programs to their area and their loyal leader's locality. The local leaders establish good connection with the DDC staffs and local officers. In return of it, the bureaucrats become the chief guests of the party's and NGOs program in their working hours. As a result, they have better access to resources mobilization and decision making process. The practice of 
improper distribution of resources and unhealthy competition for power and financial beneficiaries among the local elites, the needy area and community always remains backward position.

Democracy denotes citizens' participation in planning and development projects. The LSGA (1999) and the Interim Constitution of Nepal (2007) provides the right to participate in development planning activities of the local community. It stresses on the participation of all different groups from the community in decision making process in order to make local planning and management participatory and sustainable. The Participatory District Development Planning process consists of fourteen steps. In the field of management of development projects, such steps unite central government with the local government that influences the decision making. The planning process and the selection of the projects are no more participatory in reality. It has been replaced into 'a purely administrative apparatus'. They are based on personal whims and interest of the influential persons. The local bureaucrats prepare documents and select projects and programs without local input (Key, 2013; 100). It has resulted in non-transparency in the selection of local development plans and programs and the targeted communities are unable to get benefits and service by the state due to non attention to marginalized groups. The haphazard manner project selections are one of the main reasons of failed or ineffective development outcomes. Mukti Rijal, the authors of the "Democratizing Democracy: a Critical Challenge", writes, in an article, entitled Local Development Planning,

District Development Committees, municipalities and even some capable VDCs have formulated their periodic plans and conceptualized their annual plans with reference to the periodic plans. However, the 14-step planning process has been totally 
disrespected, and projects evolved at the grassroots that are based on the genuine needs of the people have been shelved and sidelined. The big shots at the decision-making level and powerful politicians control and override the defined statutory planning process and plan their own pet projects to support their respective constituencies.

The continued vacuum at local level has personalized and centralized the planning and selection of the projects. At central level, conflict also emerge between the Prime Minister and the National Planning Vice -Chairman over lists of the projects selection. These projects are chosen without consideration of feasibility.

\section{Decentralization of Sharing Culture and Local Democracy}

Sharing of higher echelons of administration and military post is not a new in Nepal. Historically, it was originated during the Rana regime. During that period, Rana family occupied all the higher echelons of administration and military, there was no distinction between civil and military administration (Agrawal' 1976). Many people have lost their lives for the sake of democracy, because it is a government based on meritocracy and good governance.

The nation without elections to different tiers of governance, the culture of sharing major post in political and non political organization on the basis of party affiliation has taken root at local level too. The national daily media reports 'there is not a single organization at local level which is beyond the influence of partisan politics', take for instance, 'community schools in Jhapa are fully under political influence', 'the political interference in school's management has greatly increased after last year's 
amendment to the Education Act', although they were not free of politics even earlier. 'Political parties create their own panel to run elections in organizations like community forestry users groups, drinking water users groups, chamber of commerce and industry and school management committee'. The role of political parties dominates the entire elections process right from the selection of candidates. The control over these non-political organizations means making stronger political base for the party. As a result, 'elections are also similar to the election of political parties'. And local leaders of political parties are openly supporting either one or another candidate. In many schools, the parties have not been settled to settle disputes. Seeing the national and local politics of Nepal, the former Finance Minister Ram Sharan Mahat, writes in 'Politically Possessed', party politics has deeply penetrated into educational institutions and in the management of local level projects and institutions'. 'Trade unions and student unions are also bitterly fought on party lines'.

Sharing of portfolios among the supporters of parties in every sector is a 'political commissars'. It is a challenge to meritocracy as well as against the norm of liberal democracy. It is a renewal of feudalistic traits or the Panchyat system, the only difference is that during the Panchayat system, right to academic freedom or criticizing the regime and right to open the political organization was banned, but now it's free. The biggest worry is that the culture of placing of our man and your man has added anti-intellectual at local level too. In brief, the development of new culture at local level has damaged the concept of good governance, independent judiciary, rule of law.

\section{Informal Rules and its Practices}

Democracy is a democratic system governed by rule of law. Liberal political order is built through the rule of law, not simply 
by election. Absence of rule law increases corruption, inequality and decreases social trust in society. This leads to contradiction and conflicts in society. In the context of Nepal, rule of law breaker is everywhere. Take for instance, the constitution states the maximum of 25 ministers, including the ministers and assistant ministers, by passing this provision, every government is formed nearly double. Women's representation in the Councils of Minister is poor according to the constitution. This shows constitution is working simply on a piece of paper.

Many VDCs are running without secretary, a junior officer. A secretary looks for two or more adjoining VDCs. Beside this, the secretary has to work of distribution of social security allowances, organizing meeting, makes plans, allocates development budgets coordinates and implements all the development programmes, monitoring the use of development works. In addition to these, the 'junior officer' keeps account and performs the administrative works of 26 line ministries. . Likewise, "Keshab Poudel, (2013) writes in an article, "the police personnel are very much under pressure to look at all kinds of disputes, including the petty issues related to personal transaction and other family matters". After the earth quake, distribution of relief materials and reconstruction efforts has badly affected, due absence of elected representatives.

The businessmen are selling sub-standard and date expired goods, the petrol pump cheats the people in a number of ways. Many health centers and diagnostic centers are operating in the country without registration. There is a monitoring committee to monitor and control the market, instead taking against the wrong the doer, the employees colludes with the business men. The transporters forge union and impose syndicate, school teachers receive funds and salary for fake schools, the bank employees manipulate by 
providing exceeding the values of the collateral for the same, unilaterally increase bank loan interest. Even schools have been found existing in bag, known as jhole Bidhyalays, everything alright on paper. The middle income people are, the government employees, championed in bending the rules in number of ways. The government has established office of Abuse of Authority to control corruption in the country, the chief of the anti-graft body found involved in corruption, in the name of controlling it. There are dozens institutions and laws in the country to control corrupted, they are unable to control corruption at local level. The Transparency International-Nepal reports (the Public Service Delivery Survey: 2016), Municipalities, VDCs and DDC are third most corruption institutions in Nepal, Land Revenue ranks the first and Government Hospitals in second position in corruption (TIN 2016). The report maps the 'experiences and perceptions of service seekers in 14 public service delivery institutions that were surveyed and collected in nine districts'.

Change of government through election is a beauty of democracy. A country without its elected representatives for a long period denotes she is lagging behind in maintaining the norms and values of good governance. Jeff Key writes, democratization has resulted in the rampant politicization of Nepal's public life down to the local level (Key, 2013; 99), but also decentralization of corruption.

The print media has been reporting regular incidence of corruption and deviation of existing rules and regulation. It seems that corruptions have decentralized at local units. Development budgets get spent in the last three months of the fiscal year. Such ill intention in budget expenditures facilitates the environment for corruption, irregularity and sub-standard quality of development expenditure. On the other hand, the 
excessive use of informal rules plays an important role in the disbursement of grants through User Committees (UCs). The UCs was established for the benefits of community to monitor and participate in the execution of development works themselves. The local political leaders and the civil society, they too remain unable in establishing good governance in allocation, management and use of money. Despite wide criticism from all sectors, the government had increased the Constituency Development Fund, allowing more space for corruption, to take care of their constituencies. The parking situation in the city is in total disorder and people can hardly walk on the road because of traffic congestion. Both DDCs and the Municipalities have failed to enforce it won rules and regulations in many sectors. The middle income people, majority of them are government employees, are championed in bending the rules either this or that way. No rule of law, no democracy in future.

\section{Conclusion}

Local democracy is a micro democratic institutions at the local level (village, municipal, city, town, district, county, and equivalent local levels), created by the local community for the community and are responsive and accountable government to them. Election is the beauty of democracy. It is the entry point of empowering the people. In the context of Nepal, there has been no election to local government bodies since 1997. They are functioning through the appointed bureaucrats, when the term of the peoples elected came to an end in 2002. The political leaders, the creator of republican democratic form of government, reinstated the dissolved parliament, they conducted election of the constituent assembly twice, which is rarely held in the world, but heisted conducting local election. It is just opposite of the principle right to elect and represent own 
representatives. National integration is in crisis due to absence of elected representatives at local level.

Following the promulgation of new constitution holding local election is crucial not only to ensure people's active participation in democratic exercise but also to accelerate the pace of development at local level and implantation of constitution. After multilayer dialogue, the leaders of the major parties finally decided to hold the much awaited and long demand local polls on May $14^{\text {th }}$, 2017. It paves the way of implementation of new constitution. The constitution stipulates that the local, provincial and federal parliament election will be held within January. The Election Commission is busy in making preparation with necessary manpower and materials for holding the local elections. The donor countries have expressed their willingness to support local polls. The people are now eagerly waiting the election day to exercise their voting rights. The supporters and activities are in the race to get the party tickets to contest the elections. Both urban and rural areas, some political parties have started for canvassing for votes. But the political parties lack common vision and consensus to conduct election.

\section{References}

Agrawal, Hem Narayan, (1976). The Administrative System of Nepal: From Tradition to Modernity. New Delhi: Vikas Pub. House,

Dreze, Jean and Sen, Amartya (2002). India: Development and Participation. New Delhi: Oxford University Press.

Thapa, Ganga B.(1998). Ed. Local Self-Government in Nepal. POLSAN/ FES Germany, Kathmandu:Modern printing Press.

Inglehart, Ronald (2006). Democracy and Happiness: What 
Causes What? .Available at https://pdfs.semanticscholar. org/1d0f/1c409f46040281bde732256586faf68e00d2. pdf. Down loaded on Dec, 10/ 2016.

Interim ConstitutionofNepal(2007). Availableat http://nnfsp.gov $\mathrm{np} /$ PortalContent.aspx ? Doctype $=$ Resources\&ID=214.

Jef Key (n.d.) "Nepal in Crisis: Democratization and the Failure of Local Government". In Dhirendra K. Vajpeyi (ed) Local Democracy and Politics in South Asia. Vol.3, pp. 93-113.

Poudel, Kehshab (2013). Local Bodies in Disarray. Available at http://www.spotlightnepal.com/2013/03/09/localbodies-in-disarray-only-polls-will-fix-it/.

The Constitution of Nepal (1990). Available at http://himalaya. socanth.cam.ac.uk/collections/rarebooks/downloads/ Nepal_1990_Constitution_English.pdf.

Konrad Adenauer Stiftung (2011). Political Parties : Functions and Organization in Democratic Societies. Available at http://www.kas.de/wf/doc/kas_7671-1442-2-30. pdf?120920114650. Down loaded. Dec. 22, 2016.

The Transparency International-Nepal (2016). A Survey on service Delivery http://www.tinepal.org/a-survey-onpublic-service-delivery/ . Down loaded on, Dec.28/2016

U.N (2006). Public Administration and Democratic Governance: Government Serving Citizens. UN Publication. Available at http://docplayer.net/9186671-Public-administrationand-democratic-governance-governments-servingcitizens.html. 